Jurnal Ilmu Keolahragaan Vol. 17 (2), Juli-Desember 2018: 6 - 10

\title{
IDENTIFIKASI TINGKAT KETERAMPILAN SEPAK BOLA SISWA PUTRA KELAS V SDN MONTA KECAMATAN MONTA KABUPATEN BIMA TAHUN AJARAN 2018-2019
}

\author{
Dilli Dwi Kuswoyo*
}

\begin{abstract}
Abstrak : Identifikasi tingkat keterampilan sepak bola siswa Putra kelas V SDN Monta Kecamatan Monta Kabupaten Bima tahun ajaran 2018-2019. Adapun kendala dan kekurangan terhadap keterampilan dari siswa laki-laki dalam bermain bola yaitu: Kurang memahami cara lemparan kedalam, Passing dan mengumpan pada teman kurang akurat, dan Kerja sama tim belum terlalu di kuasai siswa pada keterampilan dasar yang baik dalam bermain sepak bola. Penelitian ini bertujuan untuk mengetahui tingkat keterampilan dasar bermain sepak bola siswa putra kelas V SDN Monta Kabupaten Bima.Peneletian ini merupakan penelitian kuantitatif yang menggunakan metode survei dan teknik pengumpulan datanya menggunakan teknik tes keterampilan. Sumber data dalam penelitian ini adalah seluruh siswa putra kelas VI SDN Monta tahun ajaran 2018/2019 yang berjumlah 24 siswa. Teknik analisa data ini menggunakan teknik analisa deskriptif dengan metode survei dengan teknik tes dan pengukuran.

Berdasarkan hasil penelitian dan pembahasan dapat disimpulkan bahwa tingkat keterampilan dasar bermain sepak bola siswa putra kelas V SDN Monta tidak ada yang berkategori baik sekali dan baik atau 0\%, 55,55\% berkategori sedang, 38,89\% berkategori kurang, dan 5,56\% berkategori kurang sekali itu di karenakan kualitas yang di miliki oleh siswa kelas V SDN Monta hanyalah sedikit memahami tekhnik dasar dari permainan sepak bola ini sehingga hasil yang di tempuh hanyalah setengah saja.
\end{abstract}

Kata kunci : Keterampilan Sepak Bola, Siswa Putra.

\section{PENDAHULUAN}

Pendidikan jasmani sering kali terkalahkan oleh pendidikan akademis lainnya, padahal aspek kesehatan jasmani merupakan aspek penting guna mendukung pendidikan di sekolah. Sebagaimana diketahui bersama bahwa di dalam tubuh yang sehat terdapat jiwa yang kuat, ungkapan itu mengandung arti jika tubuh dan pikiran sehat maka siswa pun mudah menyerap pelajaran yang disampaikan oleh guru.

Tujuan pendidikan Jasmani yang ingin dicapai bukan hanya untuk mengembangkan individu dari segi fisik saja, melainkan dari segi mental, sosial, emosional, dam intelektual yang dilakukan melalui gerak tubuh atau melalui kegiatan jasmani. Menurut Rusli Lutan (2002: 2) Pendidikan memberikan kesempatan pada siswa untuk: 1) mengembangkan pengetahuan dan kemampuan yang berkaitan dengan aktifitas jasmani, perkembangan estetika dan perkembangan sosial, 2) mengembangkan kepercayaan diri dan kemampuan untuk menguasai gerak dasar yang akan mendorong partisipasinya dalam aneka aktifitas jasmani, 3) memperoleh dan mempertahankan derajat kebugaran jasmani yang optimal untuk melaksanakan tugas sehari-hari secara efisien dan terkendali, 4) mengembangkan nilai-nilai pribadi melalui partisipasi dalam aktifitas jasmani baik secara berkelompok maupun perorangan, 5) berpartisipasi dalam aktifitas jasmani dapat mengembangkan katerampilan sosial, 6) menikmati kesenangan dan keriangan melalui aktifitas jasmani, termasuk permainan olahraga.

Pendidikan jasmani mencakup beragam ruang lingkup. Ruang lingkup tersebut antara lain ada cabang olahraga atletik dan permainan. Cabang atletik tersebut antara lain lari, lempar, lompat, loncat dan cabang dari permainan antara lain sepak bola, bola basket, bola tangan dan lain-lain. Pada cabang Permainan terdiri dari permainan individu dan permainan beregu. Pembelajaran Pendidikan Jasmani yang megutamakan permainan beregu diantaranya adalah permainan sepak bola. Permainan sepak bola sangat cocok untuk para siswa di sekolah, karena gerak yang dilakukan pada permainan ini dapat merangsang pertumbuhan anak.

${ }^{*}$ Penulis adalah Staf Edukatif Prodi Penjaskesrek STKIP Taman Siswa Bima 
Dilli Dwi Kuswoyo : Identifikasi Tingkat Keterampilan Sepak Bola Siswa Putra Kelas V SDN Monta Kecamatan Monta Kabupaten Bima Tahun Ajaran 2018-2019

Sepak bola merupakan cabang olahraga yang berbentuk permainan dan didalamnya terdapat beberapa macam katerampilan dasar bermain sepak bola. Dalam permaianan sepak bola katerampilan dasar yang baik akan mampu menciptakan kerjasama dan kekompakan serta meningkatkan kualitas permainan sehingga akan menghasilkan kemenangan. Keterampilan dasar bermain sepak bola dapat dikembangkan dengan mempraktikkan gerak dasar permainan bola besar sederhana dengan peraturan yang dimodifikasi. Adapun standar kompetensi dan kompetensi dasar yang digunakan untuk materi sepak bola adalah sebagai berikut:

Teknik-teknik dasar dalam permainan sepak bola ada beberapa macam, yaitu stop ball (menghentikan bola), shooting (menendang bola ke gawang), passing (mengumpan), heading (menyundul bola), dan dribbling (menggiring bola). Dalam materi pembelajaran penjaskes, sepak bola merupakan salah satu materi yang wajib ada dalam pembelajaran. Karena selain mudah dipelajari, sepak bola merupakan salah satu olahraga yang mudah dan disukai banyak orang dari yang tua, muda, pria hingga wanita. Bahkan pada zaman sekarang ini, sepak bola tidak hanya menjadi dominasi kaum adam, para wanita yang dikenal lembut pun mulai menyukai permainan yang mayoritas dimainkan oleh para laki-laki.

SDN Monta merupakan salah satu sekolah yang memasukkan materi sepak bola ke dalam materi Pembelajaran Pendidikan Jasmani. Pembelajaran sepak bola di SDN Monta sendiri belum sepenuhnya bisa dipahami dan dikuasai oleh para siswa. Hanya ada beberapa siswa saja yang pernah bermain sepak bola atau yang mengikuti pelatihan sepak bola sebelumnya akan dengan memudah memahami materi sepak bola yang diberikan. Berdasarkan hasil observasi yang dilakukan oleh peneliti bahwa SDN Monta pernah mendapatkan juara dalam pertandingan sepak bola mini di antaranya adalah juara 1 dan 2 .

Adapun kendala dan kekurangan terhadap keterampilan dari siswa laki-laki dalam bermain bola yaitu: Kurang memahami cara lemparan kedalam, Passing dan mengumpan pada teman kurang akurat, dan Kerja sama tim belum terlalu di kuasai. Berdasarkan dari pengamatan sekilas yang dilakukan oleh peneliti pada siswa putra kelas V SDN Monta Tahun 2018, siswa belum mempunyai keterampilan dasar yang baik dalam bermain sepak bola. Oleh karena itulah peneliti tertarik untuk melakukan penelitaian secara mendalam mengenai "Identifikasi Tingkat Keterampilan Dasar Sepak bola Siswa Putra Kelas V SDN Monta Kecamatan Monta Kabupaten Bima".

\section{Pengertian Sepak bola Secara Umum}

Sepak bola adalah salah satu olahraga yang diberikan dalam pelajaran pendidikan jasmani di SD. Olahraga ini dimainkan oleh dua kelompok, dimana masing-masing kelompok beranggotakan sebelas orang. Tujuannya adalah masing-masing berusaha untuk memasukkan bola ke gawang lawan dan berusaha mempertahankan bola agar tidak kemasukan bola dari lawan.

Sepak bola merupakan permainan beregu yang terdiri dari sebelas pemain, dan salah satunya adalah penjaga gawang (Sucipto dkk, 2000: 7). Di dalam memainkan bola, setiap pemain diperbolehkan menggunakan seluruh anggota badan kecuali tangan dan lengan. Hanya penjaga gawang yang diperbolehkan memainkan bola dengan kaki dan tangan.

\section{Pengertian Keterampilan Dasar Sepak Bola}

Keterampilan seharusnya mendapat perhatian pada tingkat awal, dan pengajaran berlangsaung berkesinambungan. Istilah terampil dapat dinyatakan untuk menggambarkan tingkat keahlian seorang dalam melaksanakan tugas. Menurut Rusli Lutan (2000) keterampilan dipandang sebagai satu perbuatan atau tugas, dan lainnya sebagai sebuah indikator dan tingkat keterampilan. Keterampilan merupakan derajat keberhasilan yang konsisten dalam mencapai suatu tujuan dengan efisien dan efektif. Suatu keterampilan ada keharusan untuk pelaksanaan tugas yang terlepas dari unsur kebetulan dan untung-untungan (Singer dalam Amung Ma'mun dan Yudha M Saputra, 2000:16).

\section{Hakikat Sepak bola untuk Anak SD Usia 10-11 Tahun}

Adapun mengenai peraturan sepak bola harus disesuaikan pula dengan kondisi tumbuh kembang anak usia sekolah dasar, sebagai bahan acuan dapat dilihat dalam buku pedoman Peraturan Sepak bola Siswa Sekolah Dasar (Depdiknas, 2005: 132) dalam (Sampurno Lego Wibowo, 2010: 16), dikemukakan tentang peraturan tersebut: a) Ukuran lapangan $27,5 \mathrm{~m} \mathrm{x} \mathrm{18,3} \mathrm{m,} \mathrm{b)} \mathrm{Tiang} \mathrm{gawang} \mathrm{lebar,}$ c) 3,6 m, tinggi $1,8 \mathrm{~m}$, c) Lama pertandingan $2 \times 15$ menit.Bola yang digunakan adalah ukuran $4, \mathrm{~d}$ ) Jumlah pemain dalam satu tim adalah 7 orang pemain ( 5 pemain inti dan 2 pemain cadangan), e) 
Jurnal Ilmu Keolahragaan Vol. 17 (2), Juli-Desember 2018: 6 - 10

Sistem pertandingan adalah 5 lawan 5 pemain dari masing-masing tim, f) Tidak ada tendangan sudut, g) Bola keluar dilakukan lemparan ke dalam, h) Tidak ada offside, i) Semua tendangan bebas tidak boleh langsung ke arah gawang, j) Penalti dilakukan seperti major league soccer (dari tengah lapangan, sampai dengan gol hanya dibolehkan dua kali sentuhan), k) Pergantian pemain rolling play, 1) Bila terjadi draw diadakan sudden death, bila masih draw diadakan adu tendangan penalti, m) Peraturan lain seperti sepak bola pada umumnya.

Sedangkan menurut Kemendiknas (2010: 124-125) dalam Dwi Wahyu Utomo (2011: 21) hakikat sepak bola untuk anak usia 10-11 tahun adalah : a) Jumlah pemain tiap regu 7 anak, b) Waktu pertandingan 2x20 menit, c) Ukuran lapangan Panjang: 60 meter, Lebar: 40 meter, d) Ukuran gawang Tinggi: 2 meter, Lebar: 5 meter, e) Titik pinalti 9 meter dari gawang.

Beberapa hasil penelitian relevan yang terkait dengan penelitian ini adalah sebagai berikut:

Penelitian yang relevan dengan penelitian ini adalah sebagai berikut: 1) penelitian milik Sempurno Lego Wibowo (2010) yang berjudul "Katerampilan Dasar Bermain Sepakbola Siswa Kelas V SD Negeri Condongcatur Depok Sleman Yogyakarta". Penelitian ini bertujuan untuk mengetahui tingkat katerampilan dasar bermain sepak bola siswa kelas V Negeri Condongcatur Depok Sleman Yogyakarta. Populasi dalam penelitian ini adalah siswa putra kelas V SD Negeri Condongcatur Depok Sleman tahun ajaran 2010/2011. Sampel yang digunakan adalah seluruh populasi sebanyak 31 siswa putra. Instrumen yang digunakan adalah tes ketramapilan sepak bola usia 10-12 tahun dari Daral Fauzi R (2009), yang meliputi 6 butir tes katerampilan sepak bola usia 10-12 tahun: dribbling, passing bawah, lemparan ke dalam, berlari dengan bola, heading dengan bola, tendangan ke gawang dengan bola. Teknik analisis data yang digunakan adalah statistik deskriptif. Hasil penelitiannya tidak ada siswa yang masuk kategori baik sekali atau sebesar $0 \%$, kategori baik sebanyak 14 siswa atau sebesar 45,161 \%, kategori sedang sebanyak 15 siswa atau sebesar 48,387 \%, kategori kurang sebanyak 2 siswa atau sebesar 6,452\% dan tidak terdapat siswa putra kelas V yang masuk ke dalam ketegori kurang sekali. 2) Penelitian yang dilakukan oleh Dwi Wahyu Utomo (2011) dengan judul "Tingkat Bermain Sepak bola Siswa Sekolah Sepak Bola Putra Grabag Usia 10-12 Tahun". Penelitian ini bertujuan untuk mengetahui tingkat katerampilan teknik bermain sepakbola siswa SSB Putra Grabag. Sampel yang digunakan tes buatan Daral Fauzi R. (2009). Hasil penelitian baik sekali sebanyak 0 anak, atau $0 \%$, baik sebanyak 2 anak atau sebesar $6,67 \%$, sedang sebanyak 5 anak atau $83,33 \%$, kategori kurang sebanyai 3 anak atau $10 \%$, dan kurang sekali sebanyak 0 anak atau sebesar $0 \%$.

\section{METODE}

Populasi dari penelitian ini adalah seluruh siswa putra kelas VI SDN Monta tahun ajaran 2018/2019 yang berjumlah 24 siswa. Sampel penelitian yang digunakan sebanyak 18 siswa yang meliputi usia 11-12 tahun. Peneletian ini merupakan penelitian kuantitatif yang menggunakan metode survei dan teknik pengumpulan datanya menggunakan teknik tes keterampilan. Metode penelitian kuantitatif dirancang untuk mengumpulkan informasi tentang keadaan nyata sekarang. Menurut Syamsudin \& Damiyanti (2011) menyatakan bahwa penelitian kuantitatif adalah penelitian yang bertujuan menjelaskan fenomena yang ada dengan menggunakan angka-angka untuk mencadarkan karakteristik indiiduatau kelompok.

Teknik pengumpulan data yang digunakan adalah metode survei dengan instrumen tes dan pengukuran. Pengumpulan data yang menggunakan metode survei mempuyai tujuan untuk menetapkan atau mempertajam suatu rencana. Pengambilan data penelitian ini dilaksanakan di lapangan sepakbola SDN Monta yang beralamat di Desa Monta, Kecamatan Monta, Kabupaten Bima.

Pelaksanaan tes keterampilan sepakbola dilaksanakan pada bulan Agustus 2018 di lapangan sepakbola SDN Monta. Pelaksanaan diawali dengan tes dribbling, yaitu semua siswa melakukan tes dribbling terlebih dahulu. Siswa yang telah melaksanakan tes dribbling langsung pindah menuju tes short passed, throw in, running with the ball, heading the ball, dan yang terakhir adalah tes shooting at the ball. 
Dilli Dwi Kuswoyo : Identifikasi Tingkat Keterampilan Sepak Bola Siswa Putra Kelas V SDN Monta Kecamatan Monta Kabupaten Bima Tahun Ajaran 2018-2019

\section{HASIL}

Variabel penelitian ini adalah keterampilan dasar permainan sepak bola Siswa putra kelas V SDN MONTA.Standar tingkat kemampuan dasar permainan sepak bola dibuat berdasarkan data dari tes keteram pilan sepak bola usia 10-12 tahun buatan Muhammad Arif 2018. Data yang diperoleh dari tes tersebut digunakan untuk mengkategorikan menjadi lima kategori yaitu, baik sekali, baik, sedang, kurang, dankurang sekali. Untuk menentukan kategori tersebut, terlebih dahulu data dikumpulkan dan dihitung dengan T-skor kemudian dikategorikan sesuai dengan norma keterampilan permainan sepak bola usia 10-12 tahun. Adapun data hasil tes yang telah dilakukan sesuai dengan norma-norma tiap item tes, Di antaranya:

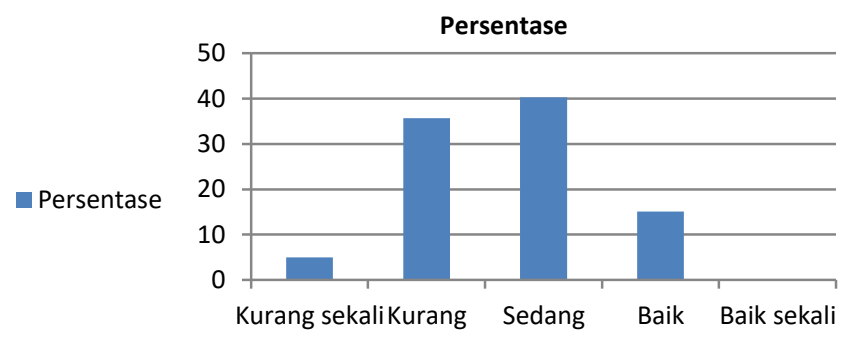

Diagram Batang Hasil Tes Passing, Throw in, Dribling, Heading, dan Shooting.

\begin{tabular}{ccccc}
\hline No & Nilai & Kategori & Frekwensi & Persentase \\
\hline 1 & $\geq 85$ & Baik Sekali & 5 & $23,23 \%$ \\
\hline 2 & $63-74$ & Baik & 5 & $23,23 \%$ \\
\hline 3 & $41-52$ & Sedang & 9 & $68,22 \%$ \\
\hline 4 & $39-40$ & Kurang & 0 & $0,00 \%$ \\
\hline 5 & $\leq 38$ & Kurang Sekali & 0 & $0,00 \%$ \\
\hline & Jumlah & & 19 & $113,68 \%$ \\
\hline
\end{tabular}

\section{KESIMPULAN DAN SARAN}

Berdasarkan hasil penelitian dan pembahasan dapat disimpulkan bahwa tingkat keterampilan dasar bermain sepak bola siswa putra kelas V SDN Monta tidak ada yang berkategori baik sekali dan baik atau 0\%, 55,55\% berkategori sedang, 38,89\% berkategori kurang, dan 5,56\% berkategori kurang sekali itu di karenakan kualitas yang di miliki oleh siswa kelas V SDN Monta hanyalah sedikit memahami tekhnik dasar dari permainan sepak bola ini sehingga hasil yang di tempuh hanyalah setengah saja.

Berdasarkan hasil penelitian yang telah dilakukan, peneliti berharap dan memberikan saran sebagai berikut:

1. Bagi siswa, hendaknya bersungguh-sungguh dalam mengikuti pembelajaran pendidikan jasmani. Terutama materi tentang teknik dasar permainan sepak bola ataupun permainan olahraga selain sepak bola karena apabila pelajaran tersebut dapat dikuasai akan memberikan hal positif bagi siswa.

2. Bagi guru, diharapkan lebih kreatif dan menggunakan metode pembelajaran yang bervariasi sehingga siswa akan lebih termotivasi untuk mengikuti kegiatan belajar mengajar sehingga tujuan dari pembelajaran itu sendiri dapat tercapai secara maksimal.

3. Bagi sekolah, agar lebih memperhatikan pengadaan sarana dan prasarana yang diperlukan dalam proses pembelajaran pendidikan jasmani.

4. Bagi peneliti selanjutnya dapat mengembangkan penelitian ini dengan menambah unsur-unsur lain seperti subjek penelitian dan menambah unsur teknik dasar sepak bola dalam keterampilan dasar bermain sepak bola untuk lebih menyempurnakan hasil penelitian ini.

\section{DAFTAR PUSTAKA}

Aip Syarifudin Muhadi. ( 1992). Atletik. Jakarta: Depdikbud. 
Jurnal Ilmu Keolahragaan Vol. 17 (2), Juli-Desember 2018: 6 - 10

Amung Ma'mun dan Yudha M. Saputra. (2000). Perkembangan Gerak dan Belajar Gerak. Jakarta: Depdikbud

Anas Sudjono. (2007). Pengantar Statistik Pendidikan. Jakarta: Grafindo Persada

Conny, Semiawan dkk. (1992). Pendekatan Keterampilan Proses. Jakarta: PT. Gramedia Widiasarana Indonesia.

Arma Abdoellah. (1981). Penguasaan Keterampilan Gerak. Jakarta: Depdikbud

Daral Fauzi. (2009). Petunjuk Pelaksanaan Tes Keterampilan Sepakbola Usia 10-12 tahun. Jakarta: Depdiknas

Depdiknas. (2006). Standar Kompetensi dan Kompensi Dasar Tingkat SD/MI. Jakarta: Depdiknas.

Dwi Wahyu Utomo. (2011). Kemampuan Dasar Sepakbola Siswa Sekolah Sepakbola Putra Grabag Usia 10-12 tahun.Skripsi UNY.

Herwin. (2004). Diklat Pembelajaran Katerampilan Sepakbola Dasar. Yogyakarta: FIK UNY

Komarudin. (2011). Diktat Pembelajaran Dasar Gerak Sepakbola. Yogyakarta: FIK UNY.

Rusli Lutan. (2002). Belajar Keterampilan Motorik Pengantar Teori dan Metode. Jakarta: Depdikbud. (2000). Strategi Belajar Mengajar Penjaskes. Jakarta: Depdiknas Sardjono.(1982). Pedoman Menyusun Permainan sepakbola. Yogyakarta: IKIP.

Sempurno Lego Wibowo. (2010). Tingkat Keterampilan Dasar Bermain Sepakbola Siswa Kelas VI SD Negeri Condong Catur Depok Sleman Yogyakarta. Skripsi UNY.

Soekatamsi. (1984). Teknik Dasar Bermain Sepakbola. Surakarta: Tiga Serangkai . (1992). Teknik dan Taktik Bermain Sepakbola. Surakarta: Tiga Serangkai

Sucipto, dkk. (2000). Sepakbola. Jakarta: Depdikbud

Sugiyanto dan Sudjarwo.(1993). Perkembangan dan Belajar Gerak. Jakarta: Depdikbud. Sugiyono. (2008). Metode Penelitian Kuantitatif dan kualitatif dan $R \& D$. Bandung: Alfabeta Suharsimi Arikunto. (2006). Prosedur Penelitian Suatu Pendekatan Praktik. Jakarta: PT.Rineka Cipta

Sukintaka. (2001). Teori Pendidikan Jasmani. Solo: ESA Grafika

Suwarno K.R. (2001).Sepak Bola: Gerak Dasar dan Teknik Dasar. FIK UNY.

Yoseph A. Luxbacher. (1998). Sepakbola. Jakarta : Grafindo Persada 